\title{
An latrogenic Intravesical Foreign Body, a Piece of Foley Catheter: Case Report
}

\author{
Iyatrojenik Bir Intravezikal Yabancı Cisim, Foley Sonda Parçası: Olgu Sunumu \\ Aliseydi Bozkurt, Mehmet Karabakan, Muzaffer Oğuz Keleş, Savaş Gündoğan, Barış Nuhoğlu \\ Clinic of Urology, Erzincan University Mengücek Gazi Training and Research Hospital, Erzincan, Turkey
}

\begin{abstract}
Although the cases of intravesical foreign body are rare, it should always be considered in the differential diagnosis of patients presenting with lower urinary tract symptoms. In general, introduction of foreign bodies into the bladder may be self- insertion through the urethra, iatrogenic, migration from adjacent organ or a result of trauma. Here we evaluated a case of intravesical foreign body that emerged following removal of a catheter was evaluated in the light of current literature. (JAREM 2014; 2: 79-81)
\end{abstract}

Key Words: Foreign body, Foley catheterization, bladder

\section{ÖZET}

Intravezikal yabancı cisim vakaları nadir görülmesine rağmen, alt üriner sistem semptomları ile başvuran hastalarda her zaman ayırıcı tanıda düşünülmelidir. Genel olarak yabancı cisim; üretra yoluyla kendi kendine yerleştirme, iyatrojenik, komşu organlardan migrasyon veya travma sonrası görülebilir. Olgumuzda sonda alınması sonrası görülen intravezikal yabancı cisim vakası güncel literatür eşliğinde değerlendirildi. (JAREM 2014; 2: 79-81)

Anahtar Sözcükler: Yabancı cisim, Foley kateterizasyon, mesane

\section{INTRODUCTION}

There are reports of intravesical foreign body cases, albeit rare, in the literature. During the last few years, reports of intravesical foreign bodies have increased in the literature (1).

In general, introduction of foreign bodies into the bladder may be self-insertion through the urethra, iatrogenic, migration from adjacent organ or a result of trauma (2).

Examples of intravesical foreign bodies include copper wire, toothbrush, pin, carrot, pencil, intrauterine devices, pieces of surgical gauze, Foley catheter and resectoscope sheath, etc. (1).

The most common complaints are dysuria, increased frequency of urination and difficulty with urination. With the development of minimally invasive techniques, most intravesical foreign bodies can be removed endoscopically without resorting to open surgery (3).

In our case, we aimed to evaluate the diagnosis and treatment of intravesical foreign bodies in the light of current literature.

\section{CASE PRESENTATION}

A 60-year-old male patient was admitted to our clinic with complaints of difficulty with urination, increased frequency and dysuria. His medical history included transurethral resection of prostate about two years ago and coronary angiography and stenting one year ago. It was learned that urethral foley catheter was inserted into the urethra during angiography and it was removed before the patient was discharged. It was also learned that he suffered from recurrent urinary tract infections and received frequent treatments periodically. In digital rectal examination of the patient, prostate was benign and palpable at half positive size. Biochemical parameters of the patient were normal and the results of his complete urine analysis (CUA) were as follows: 3 positive erythrocytes, leukocyte 1 positive, nitrite: negative, PSA: $2.5 \mathrm{ng} / \mathrm{mL}$, and there was no growth in his urine culture. In direct urinary system graph (DUSG), an opacity looking like a catheter was observed in pelvic bone region (Figure 1). In urinary tract ultrasonography (USG), no hydronephrosis was observed in the upper urinary tract and a foreign body was confirmed. Cystoscopy was performed under general anesthesia and a piece of foley catheter about $15 \mathrm{~cm}$ in length was monitored. Foley catheter was removed using foreign body forceps (Figure 2). After the procedure, the patient was discharged on $2^{\text {nd }}$ post-op day without any problem. During the patient's follow-up 1 month later, it was found that his lower urinary tract symptoms disappeared, complete urine analysis was normal and there was no growth in his urine culture. The patient gave an informed consent for publishing of data.

\section{DISCUSSION}

Bladder is the organ most frequently affected by foreign bodies in the genitourinary system. The most important cause in the etiology of intravesical foreign bodies are psychosexual disorder and accordingly the desire to masturbate. Furthermore, mental health problems such as mental disorders, self-catheterization and iatrogenic causes were also identified (1). As in the case reported by Fikri et al. (4), a piece of catheter was found to remain in the bladder, while intermittent self catheterization was applied due to urethral stricture. Foreign bodies were reported to have been accidentally placed in female urethra during pro- 


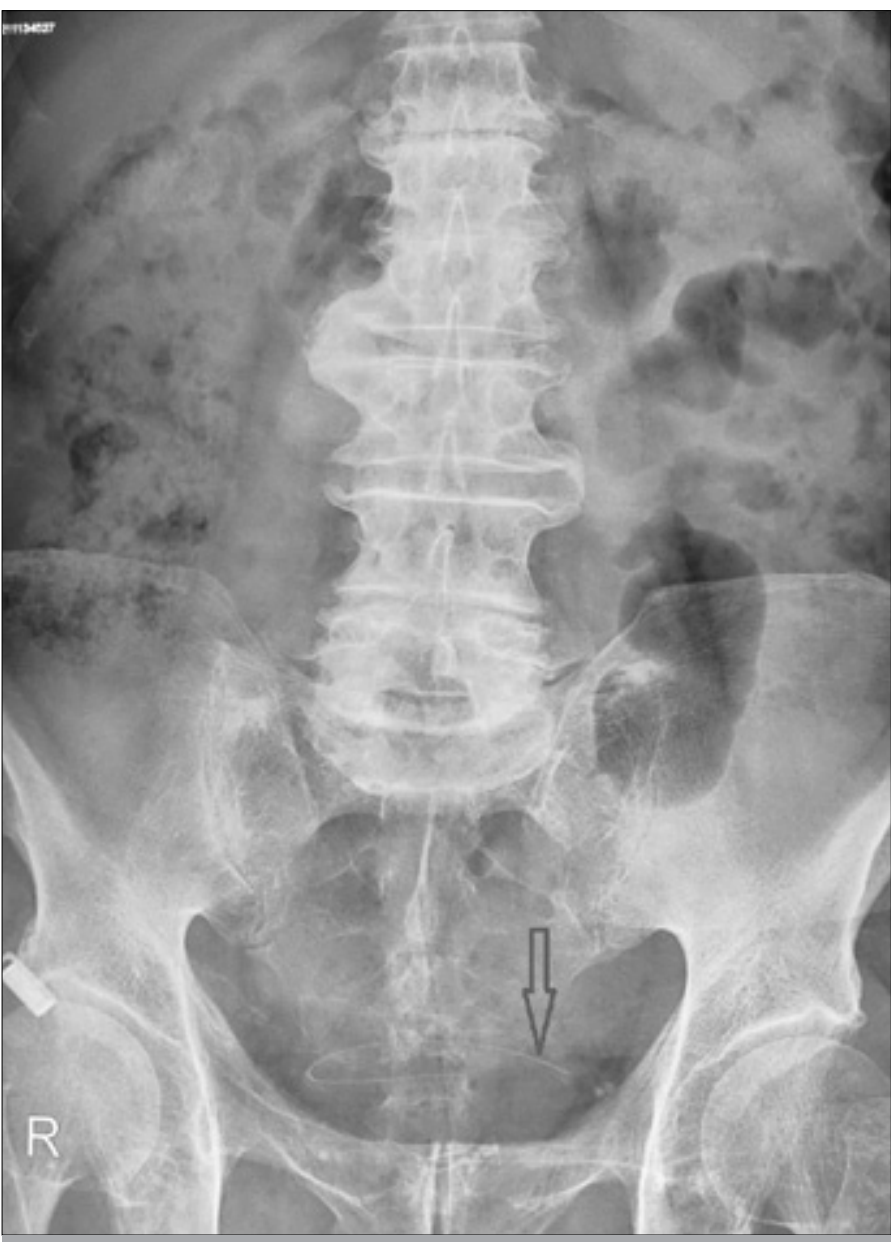

Figure 1. In direct urinary system graph (DUSG), an opacity looking like a catheter was observed in pelvic bone region

cedures conducted to have a miscarriage or prevent pregnancy (5). Recently, it has been reported that various objects such as intrauterine devices, vaginal pessaries, artificial urinary sphincter, sling, non-absorbable materials used in Stamey procedures as well as surgical gauze entered into the bladder from adjacent organs $(6,7)$. In rare cases, live objects such a leech can enter the bladder through the urethra (8). In our case, a piece of Foley catheter was found to remain in the bladder in the course of its removal procedure.

In addition to complaints of lower urinary tract, swelling of the external genitalia may occur with weak urinary flow and urinary retention in some patients. Sometimes, there may be complaints of minimal discomfort or no symptoms at all (9).

Complications such as chronic and recurrent urinary tract infections, acute urinary retention, calcification, obstructive uropathy, scrotal gangrene, vesicovaginal fistula, squamous cell carcinoma and sepsis induced death may occur in patients with intravesical foreign bodies (10).

An intravesical foreign body can be usually detected by DUSG. However, intravenous urography or computerized tomography (CT) can provide additional information in the diagnosis of nonradio-opaque foreign bodies. Urinary tract USG can also be used in the diagnosis of intravesical foreign bodies (2).

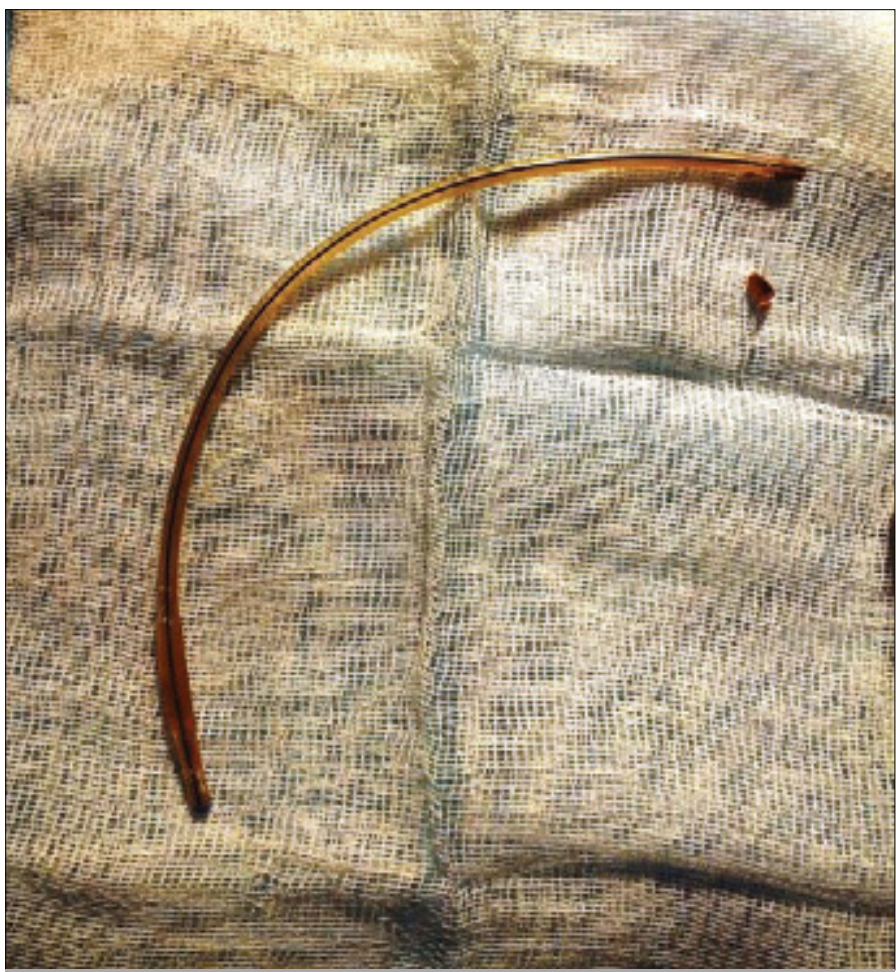

Figure 2. In cystoscopy, a $15 \mathrm{~cm}$ long foley catheter was monitored

Cystoscopy is performed to confirm the presence of an intravesical foreign body. Most foreign bodies in the bladder are removed either as a whole or in pieces by endoscopic approach. However, the best technique is determined in line with general condition of the patient, presence of any associated urinary tract injury, and size, shape and nature of the foreign body. Traditionally, a foreign body is extracted using grip forceps and basket. In the literature, foreign bodies, including a thermometer, were removed in the presence of a flexible cystoscope (11). In recent years, percutaneous and laparoscopic methods have been used to remove largescale, long and hard intravesical foreign bodies $(6,12)$.

Endoscopic methods recommended for treatment yielded fast, effective and successful results in our case. Except in rare complicated cases, endoscopic approach should be preferred for the removal of intravesical foreign bodies.

\section{CONCLUSION}

Intravesical foreign bodies is one of the problems that may be encountered by urologists, albeit rarely. It should be kept in mind that mechanic complications may occur during Foley catheterization and removal of catheter, and it should be checked whether the catheter has been removed in one piece or not. Intravesical foreign body should be suspected in patients with frequent urinary tract infections, a history of urethral catheterization, etc.

Informed Consent: Written informed consent was obtained from the patient who participated in this case.

Peer-review: Externally peer-reviewed.

Author Contributions: Concept - A.B., M.K., Design - M.K., A.B.; Supervision - B.N.; Funding - M.O.K., S.G.; Materials - S.G, M.K.; Data Collection 
and/or Processing - M.K., A.B.; Analysis and/or Interpretation - A.B., B.N.; Literature Review - M.K., A.B.; Writing - M.K., A.B.; Critical Review - B.N.

Conflict of Interest: No conflict of interest was declared by the authors.

Financial Disclosure: The authors declared that this study has received no financial support.

Hasta Onamı: Yazılı hasta onamı bu olguya katılan hastadan alınmıştır.

Hakem değerlendirmesi: Dış bağımsız.

Yazar Katkıları: Fikir - A.B., M.K., Tasarım - M.K., A.B.; Denetleme - B.N.; Kaynaklar - M.O.K., S.G.;Malzemeler - S.G, M.K.; Veri toplanması ve/veya işlemesi - M.K., A.B.; Analiz ve/veya yorum- A.B., B.N.; Literatür taraması M.K., A.B.; Yazıyı yazan - M.K., A.B.; Eleştirel İnceleme - B.N.

Çıkar Çatışması: Yazarlar çıkar çatışması bildirmemişlerdir.

Finansal Destek: Yazarlar bu çalışma için finansal destek almadıklarını beyan etmişlerdir.

\section{REFERENCES}

1. Rafique M. Intravesical foreign bodies: review and current management strategies. Urol J 2008 Fall; 5: 223-31.

2. Eckford SD, Persad RA, Brewster SF, Gingell JC. Intravesical foreign bodies: five-year review. Br J Urol 1992; 69: 41-5. [CrossRef]

3. Reddy BS, Daniel RD. A novel laparoscopic technique for removal of foreign bodies from the urinary bladder using carbon dioxide insufflation. Surg Laparosc Endosc Percutan Tech 2004; 14: 238-9. [CrossRef]
4. Fikri O, Özkan A, Kurtuluş OF, Balcı MBC, Hazar Ai, Nuhoğlu B. Üretra Darlığı Olan Bir Hastada Saptanan Mesane Iç̧i Yabancı Cisim: Olgu Sunumu, Jarem 2012; 2: 82-4.

5. Sharma UK, Rauniyar D, Shah WF. Intravesical foreign body: case report. Kathmandu Univ Med J (KUMJ) 2006; 4: 342-4.

6. Kim JH, Doo SW, Yang WJ, Song YS. Laparoscopic transvesical excision and reconstruction in the management of mid-urethral tape mesh erosion and Stones around the bladder neck: initial experiences. BJU Int 2012; 110: E1009-13. [CrossRef]

7. Nouira Y, Rakrouki S, Gargouri M, Fitouri Z, Horchani A. Intravesical migration of an intrauterine contraceptive device complicated by bladder stone: a report of six cases. Int Urogynecol J Pelvic Floor Dysfunct 2007; 18: 575-8. [CrossRef]

8. Mukherjee G. Unusual foreign body causing haematuria. J Indian Med Assoc 1974; 63: 284-5.

9. Aliabadi H, Cass AS, Gleich P, Johnson CF. Selfinflicted foreign bodies involving lower urinary tract and male genitals. Urology 1985; 26 : 12-6. [CrossRef]

10. Bhatt RI, Lau M, Ramani VAC. Renal failure secondary to a foreign body in the bladder. BJU Int 2001; 88: 644-6.

11. Scriven JM, Patterson JE. Extraction of an intravesical thermometer using a flexible cystoscope. Br J Urol 1995; 76: 815.

12. Nishiyama K, Shimada T, Yagi S, Kawahara M, Nakagawa M. Endoscopic removal of intravesical thermometer using a rigid nephroscope and forceps. Int J Urol 2002; 9: 717-8. [CrossRef] 